\title{
Q
}

ISSN 2278 - 0211 (Online)

\section{Gender Influence in Communication for Development: A Study of Migori County Government, Kenya}

\author{
Otieno Millicent Awuor \\ Lecturer, Department of Communication and Media Studies, Rongo University, Kenya \\ Jerry Agalo \\ Associate Professor, Department of Communication and Media Studies, Rongo University, Kenya \\ Dr. Peter Day \\ Senior Lecturer, Department of Information Science, University of Brighton, United Kingdom
}

\begin{abstract}
:
The goal of communication for development is to spur development among a group of people. Its aim is to evoke positive change that is empowering thereby facilitating development. Economic poverty affects both men and women however women are the majority poor. Migori County ranks 25 out of 47 counties in the poverty index ranking in Kenya (Economic Survey Report 2017). The development indices of literacy of women, fertility and child mortality in Migori County is ranked number 30, 35, 40 respectively out of the 47 counties in Kenya (Kenya Population and Housing Survey 2016). The aforementioned statistics indicate that women in Migori County are lagging behind in development. A number of development projects have been put in place by Migori county government to spur the economic development of women however the women still remain poor. The study is based on the premise that the development projects initiated by county government for women economic development are not effective because the development communication programmes are not gender sensitive. The purpose of this study was to establish the gender influence in communication for development in Migori County. The study was guided by the following objectives: establish which gender disseminates messages on development opportunities for females in Migori County, identify which gender can positively influence females in the communication of development opportunities for females in Migori County.Exploratory research design was employed as a research design for the study. Data was collected through interview responses from the county director of gender, 2 ward administrators, 10 leaders of 10 women groups, 20 members of 10 women groups found in Nyatike and Kuria West Sub counties. Focus group discussions involving 10 women from registered groups was also conducted. The total number of participants for the study was 43 . The county director of gender and the ward administrators were chosen through saturated sampling while the women were purposively sampled to take part in the study. Data collected was analyzed qualitatively through content analysis. The study found out that the county government of Migori engaged males to disseminate communication for development messages for females. On the other hand, the females in Migori County preferred that the communication for development messages be disseminated by females in order for them to understand and respond positively to the messages. The study recommends that the county government should engage more female communication specialists to advocate for gender balanced communication for development in the region. The county government should also adhere to the two third gender rule as it employs county officials so that communication for development is not dominated by one gender. The study recommends that the county government of Migori should put emphasis on gender while disseminating information on communication for development targeting females in order to have the desired influence on the females.
\end{abstract}

Keywords: Gender, influence, development, communication for development

\section{Background of the Study}

\subsection{Communication for Development}

Communication for development (C4D) was first used in the Philippines in the 1970s by Professor Nora Quebral (Manyozo, 2006), where the initial stages of communication for development were characterized by the use of mass media that considered people as audiences ready to be influenced by the messages they received (Manyozo, 2008; Agunga, 2012). In 1997, the United Nations adopted the definition of Communication for development as: Communication for development stresses the need to support two-way communication systems that enable dialogue and that allow communities to speak out, express their aspirations and concerns and participate in the decisions that relate to their development. 
The second definition emerged at the First World Congress of Communication for Development, held in Rome in October 2006. It is included in the document known as the Rome Consensus, in which the more than 900 participants of the Congress (Inagaki, 2007) agreed to conceive it as a social process based on dialogue using a broad range of tools and methods. It is also about seeking change at different levels, including listening, building trust, sharing knowledge and skills, building policies, debating, and learning for sustained and meaningful change.

In the modern times, communication for development has come to be viewed as a way to amplify voice, facilitate meaningful participation, and bring about a decisive social change through the process of sustained empowerment (Schegg and Stangl, 2017). Recently, the Communication for development Division of the World Bank, considers it as an interdisciplinary field based on empirical research that helps to build consensus while it facilitates the sharing of knowledge to achieve positive change in development initiatives (World Bank, 2015). It is not only about effective dissemination of information but also about using empirical research and two-way communication among stakeholders.

Communication for development as an art and science of human communication, has been used to achieve speedy transformation of a country and the mass of its people from poverty to a dynamic state of economic growth that makes possible greater social equality and the larger fulfilment of the human potential (Quebral, 2006; Rogers, 2016). At more regional and local scale, the process of CAD create mechanisms to broaden public access to information on reforms; strengthening clients' ability to listen to their constituencies and negotiate with stakeholders; empowering grassroots organizations to achieve a more participatory process and undertaking communication activities that are grounded in research (Servaes, 2008).

The "silent engine" that drives development endeavour is communication. In the developed world, development communication is geared toward addressing the dysfunctions of physical and material progress. In the developing world, it is concerned with the provision of physical and material infrastructure. But it is also concerned with social change in the form of inspiring hard work, eliciting self-help, and providing education, health facilities, and other critical conditions. Africa is one of the regions in the developing world where development seems to be occurring slowly (Moemena, 2007).

\subsection{Development}

Development entails the process of economic and social transformation that is based on complex sets of economic, social, cultural, socio-cultural and environmental factors and their interactions that may result in improvement of the overall human wellbeing (Ngomba, 2016; Thomas, 2017). Development is viewed as a widely participatory process of social change in a society, intended to bring about both social and material advancement, including greater equality, freedom, and other valued qualities for the majority of people through their gaining greater control over their environment (Servaes, 2008; Bourgignon, 2015). Historically it has largely been synonymous with economic development but has recently been used in a holistic and multi-disciplinary context of human development as well as other concepts like quality of life or subjective well-being (Thomas, 2017). For this study, the term development will entail human aspect of economic development as defined by Ranis, Stewart and Ramirez, (2000)

\subsection{Gender Dimension in Communication for Development}

Gender is defined as the socially constructed roles, behaviours, activities and attributes that a given society considers appropriate for men and women (WHO, 2015). As a social phenomenon, the meaning of gender is negotiated by individuals and societies and therefore varies over time and across contexts (Sen et al .2007) Women are more central than ever before to visions of global development: so why then do gender inequities remain? More money is being spent in development in the name of women's empowerment. More women are serving in roles of global leadership. More girls are being educated. But serious gender gaps in employment, in pay, in legal rights, and in leadership positions challenge the ability of both women and men to reach their potential (Wilkins, 2016).

In recent years, there has been a growing recognition on the importance of constructing a significant gender schema in communication for development globally (Moser, 2015). This follows a long-term experience that has stratified gender into explicit positions that place men above women (Lorber, 2004; Amadiume, 2015). This has seen male getting more privileges to command more power, prestige, property and economic rewards than most women regardless of the social or societal grouping. In particular, women are the subordinate group, whose positions are adjudicated to labour in the household and in the marketplace (Stern, 1997). In this connection, gender perspectives have utilized the field of cultural criticism to question the rationality of the dominant culture by revealing the way culture structurally favours men and their interests (Treichler and Wartella, 2006; Winship, 2013). Efforts have been put in place to try and enforce gender involvement in communication for development programmes aimed at establishing democratic communication and egalitarianism in society (Parpart, Rai and Staudt, 2013). The gender focus on communication therefore remains crucial as these are power structures which define reality, produce social meanings, set agenda and inform the citizenry.

\section{Research Problem}

Low uptake of development in many parts of Kenya has been acknowledged for several decades (Rees, et al, 2016). Efforts are aimed at ensuring that resources are developed into the grassroot to enhance development agenda. As a result, several counties are currently undertaking many projects aimed at alleviating poverty among the people at the local levels through the devolution programme (Clarity, 2013). One of the aims of devolution was to improve the livelihoods of the people, 
among whom, women make up a critical mass. Migori county government has initiated a number of development projects with the aim of uplifting the livelihood of women however, the women remain poor. Migori County ranks 25 out of 47 counties in the poverty index ranking in Kenya (Economic Survey 2017).The development indices of literacy of women, fertility and child mortality in Migori County is ranked number 30, 35, 40 respectively out of the 47 counties in Kenya (Kenya Housing and Population Survey 2016) The development projects failed to realize the intended objective because the county government does not recognize that the styles of communication and influence between male and female is always different. Failure to take cognizant of the gender styles for communication lead to ineffective delivery of messages of development, consequently the message fails to have the desired influence on the target audience. It is a recognized fact that the success of development efforts depends, in part, on the quality of the communication established with the populations concerned and on the taking into account of gender issues

\subsection{Objectives of the Study}

The study was guided by the following objectives:

- To establish which gender disseminates information of development opportunities for females in Migori County.

- To identify which gender can positively influence females in the communication of development opportunities for females.

\subsection{Research Questions}

The study aimed to answer the following questions:

- Which gender disseminates information on development opportunities for females in Migori County?

- Which gender can positively influence females in communication of development for females in Migori County?

\section{Literature Review}

\subsection{Gender Styles of Communication and Social Influence}

Communication does not only inform but also influences the behaviour of the receiver of information. Development communication involves a planned change in knowledge, attitudes, and practices, which influence not just the individual but other components of a system as well (Kheerajit). Participatory development communication a term coined by Bessette (2004), aims to facilitate dialogue and empowerment in community-based level interventions in Latin America, Africa, and Southeast Asia. It means moving from a focus of informing and persuading people to that of changing their behaviours or attitudes and facilitating exchanges among different stakeholders to address a common problem.

Men and women not only differ in the way in which they communicate with one another but also in the way that they attempt to influence one another. Influence is a leader's ability to motivate and influence their followers to change their behaviour, beliefs and attitudes. (Merchant, 2012). Social influence is the process by which individuals make real changes to their feelings and behaviours as a result of interaction with others who are perceived to be similar, desirable, or expert (Rashotte, 2007). Historically most research on gender and social influence has focussed on gender differences in influence ability, the extent to which men and women are influenced by others (Carli 2001). Less attention has however been devoted to the effect of a person 's gender on his or her ability to influence others (Murray 1995).

In most settings, women possess lower levels of status and power than men do , particularly power based on expertise or legitimate authority ( Carli 1999).Because men and women typically fill different roles, with women more often occupying caretaking , domestic and lower status occupational roles and men more often occupying higher status occupational roles , people expect men to behave more agentically than women and women to behave more communally than men ( Rao 1995).Moreover, given the social roles to which men and women are assigned in society ,dominant behaviour ,such as aggression and competitiveness , is prescriptively more congruent with the male than the female role ( Carli 2001).

Much research has revealed that women continue to be viewed as warmer and nicer than men ( Diekman and Eagy 2000) .Unfortunately, the stereotype of female warmth has become prescriptive : women are expected to show communal traits .Because women lack status ( Ridgeway 1995) and possess relatively low levels of legitimate power ( Carli 1999) they are penalised and rejected when they do not adhere to the prescription for warmth and communality. Women who attempt to influence others while communicating a desire for personal gain or to enhance their own status are likely to be unsuccessful .Instead people are likely to show greater receptiveness to female influence by a woman who is collaborative and whose goals appear to focus more on helping others achieve their goals than on her own benefit ( Meeker \& Weitzel O ' Neil ,1998)

The idea that women and men have different communication styles have become the theme of many best-selling books on gender differences such as the book written by Tannen's (1990) You just don't understand: Women and men in conversation and Gray (1992) titled "Men are from Mars, Women are from Venus". These books argue that there are significant and consistent differences in communication styles between men and women.

The biggest difference between men and women and their style of communication boils down to the fact that men and women view the purpose of conversations differently. Academic research on psychological gender differences has shown that while women use communication as a tool to enhance social connections and create relationships, men use language to exert dominance and achieve tangible outcomes (Leaper, 1991; Maltz \&Borker, 1982; Wood, 1996; Mason, 1994). Women are, overall, more expressive, tentative, and polite in conversation, while men are more assertive, and power-hungry (Basow \& 
Rubenfield, 2003). Men and women also differ in their relations towards men value their independence (Chodorow, 1978; Dinnerstein, 1977; Eagly, 1987; Grilligan, 1982; Miller, 1976). On the other hand, popular works by John Gray and Deborah Tannen show that that while men view conversations as a way to establish and maintain status and dominance in relationships, women see the purpose of conversation to create and foster an intimate bond with the other party by talking about topical problems and issues they are communally facing (Gray, 1992; Tannen, 1990).

Academic research has shown many differences in communication styles between men and women. Overall, women are expected to use communication to enhance social connections and relationships, while men use language to enhance social dominance (Leaper, 2011; Mulac, Bradac, \& Gibbons, 2001). On average, women use more expressive, tentative, and polite language than men do, especially in situations of conflict (Basow\& Rubenfield, 2003). Popular research has also shown gender differences in communication styles, from men being primarily goal-oriented and result-focused and women being relationship-oriented and placing a high value on closeness and intimacy in interactions with other people (Tannen, 1990; Gray, 1992). Overall, the two bodies of research on gender differences in communication styles (academic research and popular literature) tend to agree on how men and women differ in the way they communicate. While academic research focuses more on the communication characteristics and traits that men and women exhibit, popular literature makes the connection between psychological gender traits and communication styles and gender differences in terms of basic goals of conversations (Merchant 2012).

Gray (1992) suggested that men prefer to do things by themselves, tend to evaluate the competence of others when interacting and are more competitive. This is somewhat consistent with some research that have shown that men tend to value male input over female input and assume that men are more competent than women (Martin,1996; Pierce, 1995; Williams, 1995). Males are also more likely than females to intentionally withhold information to further their own positions or harm another's position (Deal, 2000). Such ways that men accomplish something have often identified them as being competent, but this is not the case when it comes to women. Men trust more than women, and women are more trustworthy than men (Buchan, Croson \& Solnick,2008). However, conversation style differences frequently lead to women being evaluated as less competent than men. Although it may seem that the female communication style might be the weaker form, it can also be said that females are more able to establish a rapport that encourages response because of their ability to empathize and connect. While males conversational style usually centers around their own independence, female communication style reflects their need for connectedness (von Hippel, Wiryakusuma, Bowden, \& Shochet, 2011). Men or also known as Martians by Gray (1992) value power, competency, efficiency, action, achievement, and accomplishment. His view on women's (he calls them "Venusians") sense of self in the work place is defined primarily by the quality of her work relationships. In the work place, Venusians respect efficiency and achievement, but values support, trust, and communication more. He also claimed that Venusians are more interested in the quality of work relationships, personal expression, and mutual support than Martians. Venusians experience fulfilment by sharing, collaborating, and cooperating in the process of achieving greater success.

Asking questions means different things to men and women, and thus the complexity underpinning the significance of asking questions is often managed in different ways. According to Tannen (1994), the language of conversation is primarily a language of rapport for women i.e. a way of establishing connections and negotiating relationships. For men, talk is primarily a means to provide information, preserve independence and negotiate and maintain status in a hierarchical social order i.e. a language of report. It has also been found that men tend to interrupt more and they are more resistant to asking questions (Tannen, 1990; Coates, 1996; Lakoff,1996). Women are more likely than men to ask questions and agree with others, and women are less likely than men to challenge others' statements and frame others' arguments. These differences are theorized to reflect women's greater concerns for cooperation and connection in their relationships. These conclusions are consistent with Gray's (1992) notion that men are more likely to interpret messages according to levels of dominance, whereas women are more likely to interpret them according to levels of supportiveness.

Overall, research has showed that, in general, women are more social emotional in their interactions with others, whereas men are more independent and unemotional (Grilligan, 1982; Miller, 1976). Theorists have suggested that these gender differences in communication styles put women at a disadvantage when interacting with others because they speak more tentatively than men, who are known to speak more assertively, thus leaving the impression that men are more confident and capable as leaders (Lakoff, 1996). Many of these gender differences in communication styles outlined make women appear subordinate to men, suggesting they should be viewed as second-class to men (Merchant, 2012).

\subsection{Conceptual Framework}

Reichel and Ramey (1987) in Kombo and Tromp, (2006) sees conceptual framework as a set of ideas and principles taken from relevant field of inquiry and used to structure subsequent presentations. Conceptual framework involves forming ideas about relationships between variables in the study and showing these relationships graphically or diagrammatically (Mugenda and Mugenda,2003).

The conceptual framework for this study has been depicted in the Figure below. In the framework the researcher intends to determine relationship between gender influence in communication for development and the prospect of development of females in Migori County. In the conceptual framework, gender perspective in communication for development is the key determinants of development agenda in the county. However, intervening variables such as county 
policy and laws on development and communication may have far reaching consequences to relationships between gender perspectives on communication for development and the prospects for actual development outcomes among females.

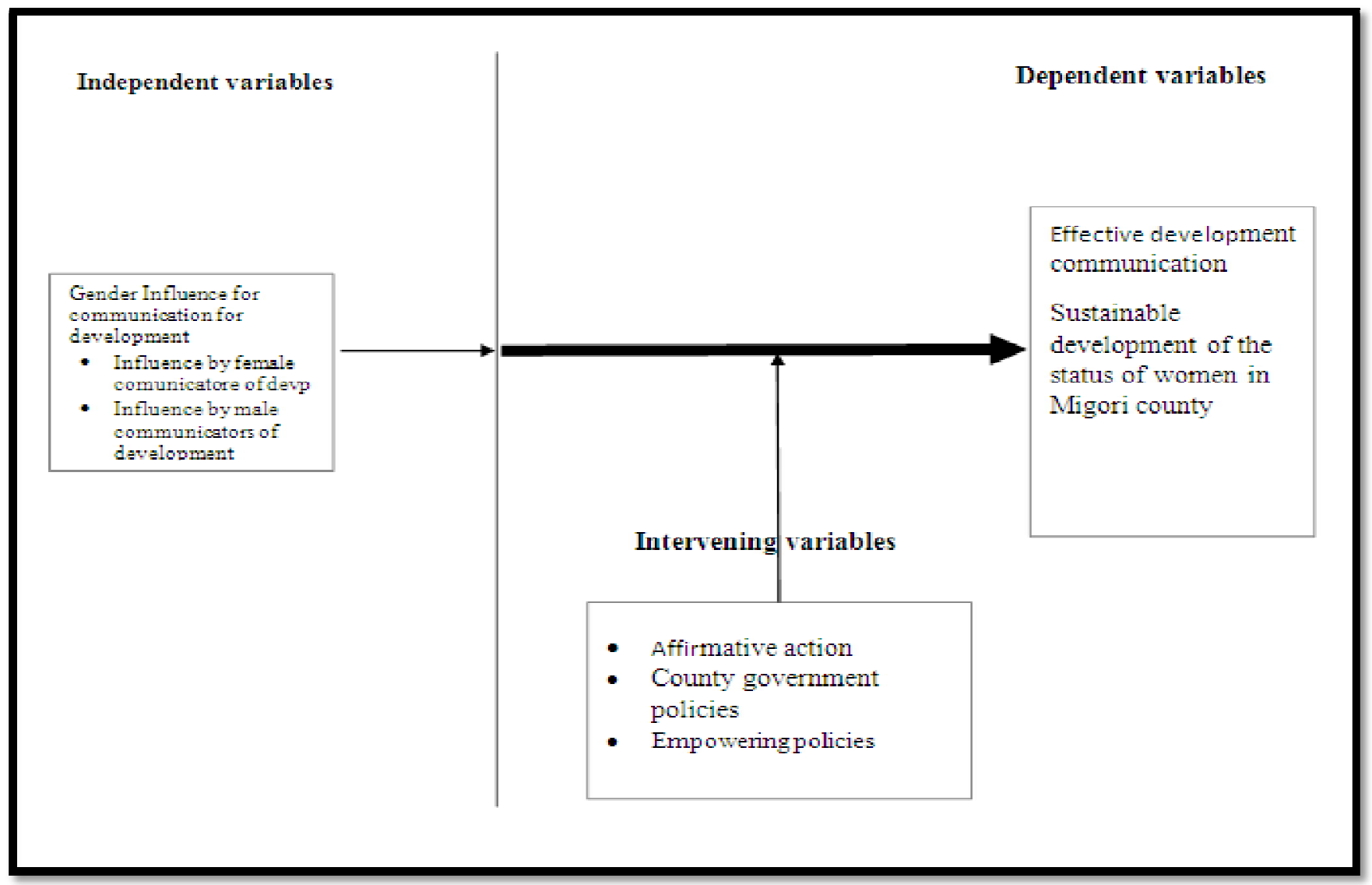

Figure 1: Conceptual Framework Showing the Relationship among the Variables of the Study

\section{Research Methodology}

\subsection{Research Design}

Good research designs help the researcher to plan and implement the study in a way that will help the researcher to obtain intended results, thus increasing the chances of obtaining information that could be associated with the real situation (Burns \& Grove 2001). Exploratory research design was employed in this research. The study sought to generate a posteriori data that tested the relationships between the independent variables and the main dependent variable. The advantage of exploratory research is that it was easier to make new discoveries due to the less stringent methodological restrictions. The study focused on gender sources of information for communication for development, the research design gave more room for interpretation and understanding.

\subsection{Sample Size and sample selection}

The major aim of sampling in research is to identify the participants who are likely to give rich and in depth information on the issue being studied so that we learn the most about it (Dörnyei, 2007).In this study, the researcher selected three categories of participants: county director of gender, ward administrators, leaders of different women groups in Nyatike and Kuria West other members of women from groups that have benefitted and members from groups that have not benefitted from the development project initiatives in the county were also purposively sampled for the study. The county director of gender was chosen because she sets, co-ordinates and implements the gender agenda within the county. She is important for the study since the office is instrumental in formulating gender policies and planning projects for women and other marginalized groups. The ward administrators were chosen because of the role they play in identifying, communicating and coordinating county government projects within the ward. The researcher therefore considered the ward administrators key in development communication. The women groups were chosen because development initiatives for females are channeled to the women through registered women groups. Leaders and members of the women groups were preferred respondents because they were a good representation of the group members who in this case are females in Migori County

The county director of gender and the ward administrators were chosen through saturated sampling. Saturated sampling technique is a non-probability sampling technique in which all $100 \%$ members of the targeted population are selected because they are two few to make a sample out of them. The women were purposively sampled for the study. 
Purposive sampling was used in this study because as Mugenda and Mugenda (1999) assert, the focus is on in-depth information on a particular issue and not on making inferences or generalizations. Hence, the study targeted participants who are known to have the information that served the purpose of this study, by virtue of their duties (Kombo and Tromp, 2006).

The study was conducted in two sub counties within Migori County: Nyatike and Kuria West. Migori County comprises of eight sub counties namely Rongo, Awendo, Uriri, Suna East, Suna West, Kuria East and Kuria West. Out of the eight sub counties, two sub counties were selected for the study because aaccording to Mugenda (2008), 30\% sample size is sufficient to represent a population to be used in social science research. Based on this theory, 30\% of the total sub counties in Migori County was used to determine the number of sub counties to be used in the study. $30 \%$ percent of the 8 sub counties in Migori County is 2 . These two sub counties were chosen through purposive sampling due to their disadvantaged economic status.

The researcher selected the following categories of participants: county director of gender, 2 ward administrators, 10 leaders of different women groups in Nyatike and Kuria West 10 other members of women from groups that have benefitted and 10 members from groups that have not benefitted from the development project initiatives in the county were also purposively sampled for the study. There was also a focus group of 10 other members of women groups: 5 beneficiaries and 5 non-beneficiaries of the county economic development programmes. The study population is 43 . According to various scholars, the question of sampling in qualitative research is rather sticky since there are no clear guidelines or standards on what may be considered the right number of samples. Most scholars agree that any sample of between 15 to 50 participants is adequate (Charmaz, 2006) suggests that 25 participants are adequate for smaller projects .According to Ritchie et al 2003, qualitative samples often lie under 50 while Green \&Thorogood (2009) state that the experience of most qualitative researchers is that the interview studies little that is new comes out of transcripts after you have interviewed 20 or so people .For ethnography and grounded theory, ( Morse, 1994 ) has suggested approximately 30 to 50 participants : while ( Cresswell, 1998) suggests between 20 and 30 participants for grounded theory and between 5 and 25 for phenomenological studies.

\subsection{Research Instruments}

During the study two main methods of data collection were employed. They include the use of in-depth interviews and focus group discussion. Tools for data collection were employed based on the indicators to be assessed and the objectives of study. The following data collection tools/ instruments were used:

\subsection{Interviews}

Interviews as a technique of generating data involve direct verbal interaction between individuals. It is intended to get what a participant in the research thinks, the attitudes of that person and/ or to explore a person's reasons for thinking in a certain way or for carrying particular perceptions or attitudes (Cohen et al, 2007). Interviews are one of the most important sources of data in qualitative research (Mugenda and Mugenda, 1999) and are advantageous in that they provide in-depth data. Interviews will make it possible to obtain data necessary to meet specific objectives of the study and also guard against confusing the questions since the interviewer can clarify the questions thereby helping the respondent give relevant responses. The interviews will enable the researcher develop a rapport with the participants and facilitate free exchange of information. According to Gillham (2005), the relationship between the interviewer and the interviewee is responsive or interactive, allowing for a degree of adjustment, clarification and exploration.

Interviews suited this study in terms of the factors noted by Gillham (2005) who says that interviews are suitable when: small numbers are involved, they are accessible, they are key and you can't afford to lose any, your questions...are mainly open and require an extended response with prompts and probes...to clarify answers, if the material is sensitive in character so that trust is involved: people will disclose things in a face-to-face interview that they will not disclose in any anonymous questionnaire. The interviews will be conducted at the participants' places of work and homes. They will be conducted in the language the participants are comfortable using, that is, English, Kiswahili, Luo and Kuria. English is the official language in Kenya and Kiswahili the national language. The two wards: Nyatike and Kuria where the study will be conducted are predominantly inhabited by the Luos and the Kurias, therefore the local dialects will be employed where the respondents neither speak English or Kiswahili. In cases where Kuria language will be the sole language employed, then the researcher will seek translation services. Since these are the four languages the participants used, the researcher allowed for flexibility so that the information could be delivered appropriately. Interviews were more flexible for the participant were able to adapt to the situation and get as much information as possible. Very sensitive and personal information can be extracted from the respondent by honest and personal interaction between the respondent and the interviewer. The interviewer can clarify and elaborate the purpose of the research so that the respondents can give more complete and honest information. Interviewers are however, able to get such information through interaction and genuine conversation. Interviews yield high response rates mainly because it is difficult for a subject to completely refuse to answer questions or ignore the interviewer (Gillham, 2005). The researcher interviewed the county director of gender, two ward administrators, a total of 10 leaders of 10 women groups, 20members from 10 different women groups found in Nyatike and Kuria West.

\subsection{Focus Group Discussions}

In focus group discussions (FGDS), a group of people are asked about their perceptions, beliefs and attitudes by the interviewer (Cresswell 1994). The focus group discussions usually consist of 6 to 12 members (Berger 2009). The focus group discussions were guided by semi structured questions. Semi structured questions were preferred because they are more 
flexible and thus generate reliable data. The FGDs are considered important for this study because data is collected in a large group of environments, which provides a large volume of information from variety of perspective. FGDs provide an environment where participants express ideas without fear of criticism as well as create a fuller and deeper understanding of the phenomenon being studied. FGDs also stimulate spontaneous exchange of thoughts, ideas and attitudes in the security of being in a crowd (Des Vos et al 2011).

According to Nielsen (1979), FGDs often bring out participants spontaneous reactions and ideas and let the researcher observe some group dynamics and organizational issues. This is because in many the FGD is conducted as an open conversation in which each participant may comment on other participants' answers or respond to comments by others. To encourage wider participation and deal with dominant members, participants should be told that the presence of each of them and their perceptions are important for the discussion. At a practical level, FGDs are efficient in the sense that they generate large quantities of material from relatively short time. Equally, they foreground the importance not only of content, but also of expressions, because they capitalize on the richness and complexity of group dynamics (Kamberelis and Dimitriadis 2005)

One weakness of FGD is that it may be difficult to determine whether an individual's process is subject to group influence (Casey and Krueger 2000). Other problems may also arise from group management and logistics. However, these problems can be considered as part of the group dynamics which are useful for the study.

The researcher conducted a focus group discussion of 10 women. 5 members of the group were from groups that had benefitted from the county government development initiatives and the other 5 members were from groups that had not benefitted from the initiatives. This mix ensured a balanced view of development communication in Migori County.

\subsection{Data Analysis}

Thematic analysis was done to analyze qualitative data in the study by emphasized indicative, examining and recording patterns within data (Braun and Clark,2006). The process involved transcribing and coding so as to create meaningful patterns. According to (Mugenda and Mugenda, 2003), the process included six steps: becoming familiar with the data, generating initial codes, searching for themes, reviewing themes, defining and naming themes and producing report.

The data was first transcribed and checked for accuracy aided by content analysis. (Orodho,2009), defines Content analysis as a procedure for categorization of verbal or behavioural data for purpose of classification, examining the intensity with which certain words, points of view and emotionally laden words are used to express experiences. The, codes were generated and data collated significant to each code. Emerging themes were noted from each code and collated into potential themes. The potential themes were reviewed by checking against the coded extracts leading to a thematic map of the analysis. The themes were then refined into specifics by generating clear definitions and names for each theme. Finally, there was a selection of vivid extracts from the transcriptions, relating back of the analysis to the research questions and literature as per themes and objectives (Braun and Clark,2006).

\section{Findings}

\subsection{Gender Influence in Communication for Development in Migori County}

The study sought to find out who between male and female the respondents would prefer to communicate development issues in Migori County. To answer this, the following question was asked: Which gender can positively influence you in communication for development Migori county?

The study found out the respondents that the females believe, females can positively influence them in communication for development. They also indicated that they prefer that females communicate development issues to them in the county. The following responses were common among respondents who preferred females to be the communicator of development in Migori County:

'Females have convincing powers and are transparent and genuine

Females understand female's development status

Females speak better through

It would be easy to express myself without any hesitation or fear or will be able to understand better what women go

Even though the preferences for male communicators of development was minimal, the responses are worth noting. The following responses were given by respondents who preferred males as the communicator of development in Migori County:

Male have knowledge

Men are more conversant with development issues

I trust men more

Men have personality and confidence when it comes to conveying important matters

The county director of gender, the ward administrators were also asked this question: Who disseminates the messages of development for females in the Migori County? The study found out that development messages for females was disseminated by whoever was available irrespective of gender. The messages were disseminated more by males being that there were more males than female employees in the county. 
County director of gender:

I as female, disseminates development messages to females, when I cannot do it on my own, then a member of my staff does it. In my department, I have five males and two females so any one can do it. the dissemination of the messages is done by whoever is available. Since I have more male than female employees, then most of the time the function is performed by a male

Ward administrator:

I am male, I disseminate the development messages for females. I also let the chiefs do it at barazas. In this ward, there is only one female chief the other four are males. To add to that, In the county, there are 40 ward administrators, only 5 are females

\section{Conclusion}

The county government officials represented by the director of gender and ward administrators indicated that the dissemination of development messages for females was done by males. The county director of gender indicated that among the employees in her department were more males than females. The ward administrators also indicated that it is the males who disseminated development communication messages since out of the 40 ward administrators in Migori County only 5 were females. On the other hand, the females in Migori County prefer that the communicator of development opportunities for females should be female. The preference for female communicator of development by females in Migori County is supported by (Rashotte, 2007) who indicates that social influence is the process by which individuals make real changes to their feelings and behaviours as a result of interaction with others who are perceived to be similar.

The females preferred female communicators for different reasons. They indicated that: 'Females understand females development status'. This is in consistent with the findings of Meeker \& Weitzel (1998) that people are likely to show greater receptiveness to female influence by a woman who is collaborative and whose goals appear to focus more on helping others achieve their goals. Another recurring response was that 'It would be easy to express myself without any hesitation or fear or will be able to understand better what women go through.' This response is consistent with the findings of Gray, (1992) and Tannen, (1990) which show that women see the purpose of communication to create and foster an intimate bond with the other party by talking about topical problems and issues they are communally facing. Von Hippel, Wiryakusuma, Bowden, \& Shochet, (2011) In their work -Stereotype threat and female communication style also agree with the findings of John Gray and Deborah Tannen when they state that although it may seem that the female communication style might be the weaker form, it can also be said that females are more able to establish a rapport that encourages response because of their ability to empathize and connect. While male communication style usually centers around their own independence, female communication style reflects their need for connectedness. This therefore points to the possibility of females to easily influence other females in the process of communication for development.

The other reason for preference for females is that: females speak better This finding is a contrast of other findings that report that females are inferior in communication competence. Findings by Martin, (1996), Pierce, (1995) and Williams, (1995) indicate that men tend to value male input over female input and assume that men are more competent than women. These findings were however based on response from men while this study only focussed on the views of females. Further, according to Buchan, Croson \& Solnick, (2008) communication style differences frequently lead to women being evaluated as less competent than men. There is need to further investigate the communication competence of males and females. However, the fact that the respondents believe that female speak better than males could point to an emerging acceptance of the capability of females in the realm of communication. The respondents also indicated that prefer communicators for development because 'Females have convincing powers and are transparent and genuine. This is in consistence with the finding of Deal, (2000) that indicate that males are also more likely than females to intentionally withhold information to further their own positions or harm another's position. The transparent and co-operative nature of females can therefore be harnessed to improve communication for development targeting females.

The reasons for preference for male communicators of development cannot also be ignored. One of the reasons for preference for male communicators of development is that males are confident. This response corresponds with the findings of Lakoff (1996) that indicate that theorists have suggested that these gender differences in communication styles put women at a disadvantage when interacting with others because they speak more tentatively than men, who are known to speak more assertively, thus leaving the impression that men are more confident and capable as leaders.This calls for training of female communicators of development to be confident so that the messages of development being disseminated can have an effect on the target audience. This finding by Lakoff, (1996) can also explain the reason why the females think that men are more conversant with development issues.

I trust men more', this was another reason given by a respondent for justifying her response for male communicators of development. This response could be evoked by the hierarchical position of males and females in the society. Lorber, (2004) \& Amadiume, (2015) agrees that there is a long-term experience that has stratified gender into explicit positions that place men above women. The society places men in a position higher than women. So, men are likely to be trusted more than females. This sex role leaning leads women to convince themselves that they are subordinate to men and subsequently leads to a culture trap (Claes, 1999). In order, to break such stereotypes there is need for a shift in socialisation where females and males will be nurtured as equals of each other. 


\section{Recommendations}

The study recommends that the county government of Migori should put emphasis on gender while disseminating information on communication for development targeting females. The messenger is as important as the message. Therefore, the county government should give importance to the preference of females in who should communicate development issues to women. In particular female county officials should be charged with the responsibility of communicating development for females in Migori County. In addition, gender influence is a critical component in communication for development. The gender of the sender of information of development is important in order to have the desired response from the target audience. So as the messages of development are disseminated, it is important to have a match between the gender of the person disseminating the information and the gender of the receiver of the information.

The county government should adhere to the two third gender rule as it employs county officials so that communication for development is not dominated by one gender. This will ensure gender inclusivity in communication for development. Further, the person delivering the information on development must also possess the appropriate communication competencies.

\section{Suggested Areas for Further Research}

Further research can be done to establish:

- Influence tactics employed in development communication targeting females

- Influence of female communicators on the development uptake of females

- The preferences of the sender of communication for development for other groups such as the youth, the people with disability among others.

\section{References}

i. Agunga, R. (2012). Communication for development: A personal experience with implications for development policy. The Journal of Agricultural Education and Extension. 18: 509-524.

ii. Amadiume, I. (2015). Male daughters, female husbands: Gender and sex in an African society. Zed Books Ltd.

iii. Basow, S. A., \& Rubenfeld, K. (2003). "Troubles talk”: Effects of gender and gender-typing. Sex roles, 48(3-4), 183-187.

iv. Bourgignon, F. (2015). Equity and economic growth: Permanent questions and changing answers? Background paper prepared for the 2016 Human Development Report, UNDP, New York.

v. Buchan, N. R., Croson, R. T., \& Solnick, S. (2008). Trust and gender: An examination of behavior and beliefs in the Investment Game. Journal of Economic Behavior \& Organization, 68(3-4), 466-476.

vi. Bryman, A., \& Cramer, D. (1999). Quantitative data analysis with SPSS release 8 for Windows. A guide for social scientists. London and New York: Taylor \& Francis Group.

vii. Casey, M. A .\& Krueger, R. A. (2014). Focus groups: A practical guide for applied research. Sage publications.

viii. Carli, L. L., \& Eagly, A. H. (1999). Gender effects on social influence and emergent leadership.In G .Powell ( Ed) ,Handbook of gender in organizations. Thousand Oaks,CA:Sage

ix. Carli, L. L. (2001). Gender, interpersonal power, and social influence. Journal of social issues, 55(1), 81-99.

x. Charmaz, K. (2006). Constructing grounded theory: A practical guide through qualitative research. SagePublications Ltd, London.

xi. Chodorow, N. J. (1999). The reproduction of mothering: Psychoanalysis and the sociology of gender. Univ of California Press.

xii. Claes, M.T. (1999), Women, men and management styles, International Labour

xiii. Review, Vol. 138 No. 4, 431-46.

xiv. Clarity, R.G. (2013). Devolution inKenya.https:/ / www.wsp.org/ sites/ wsp.org/ publications/ devolution-in-Kenya-.pdf.

xv. Cohen, S. I. (1996). Mobilizing communities for participation and empowerment. Participatory communication for social change, $24,223$.

xvi. Creswell, J. W. (1994). Research design: Qualitative \& quantitative approaches. Sage Publications, Inc.

xvii. Creswell, J. W., \& Inquiry, Q. (2007). Research design: choosing among five approaches.

xviii. Deal, J. J. (2000). Gender differences in the intentional use of information in competitive negotiations. Small Group Research, 31(6), 702-723.

xix. De Vos, A. S., Delport, C. S. L., Fouché, C. B., \& Strydom, H. (2011). Research at grass roots: A primer for the social science and human professions.

xx. Diekman, A. B., \& Eagly, A. H. (2000). Stereotypes as dynamic constructs: Women and men of the past, present, and future. Personality and social psychology bulletin, 26(10), 1171-1188.

xxi. Dinnerstein, L. (1977). The East European Jewish Migration. Uncertain Americans: Readings in ethnic history, $216-31$.

xxii. Dornyei, Z. (2007). Research methods in applied linguistics.

xxiii. Eagly, A. H. (1987). The interpretation of sex differences in social behavior. Sex differences in social behavior: A socialrole interpretation. London: Lawrence Erlbaum Associates.

xxiv. Economic Survey (2017). Ministry of Devolution and Planning.www.devolutionplanning.go.ke.

xxv. Gilham, B. (2005). Research interviewing: the range of techniques. Continuum, London.

xxvi. Gilligan, C. (1982). In a different voice. Psychological theory and women's development. 
xxvii. Gray, J. (1992). Men are from Mars, Women are from Venus: a Practical Guide forImproving Communication and Getting What You Want in a Relationship. HarperCollins, New York

xxviii. Green, J., \& Thorogood, N. (2009). Principles and approaches in qualitative research.

xxix. Inagaki, N. (2007). Communicating the impact of communication for development. Washington, DC: The World Bank.

xxx. Ridgeway, C. L., Diekema, D., \& Johnson, C. (1995). Legitimacy, compliance, and gender in peer groups. Social Psychology Quarterly, 298-311.

xxxi. Jwan, J. O., \& Ong'ondo, C. O. (2011). Qualitative research: An introduction to principles and techniques. Eldoret, Moi University.

xxxii. Kamberelis, G., \& Dimitriadis, G. (2005). Focus groups: strategic articulations of pedagogy, politics, and research practice. Handbook of qualitative research, 875-895.

xxxiii. Kombo, D. K., \& Tromp, D. L. (2006). Proposal and thesis writing: An introduction. Nairobi: Paulines Publications Africa, 10-45.

xxxiv. Kothari, C. R. (1990). Research Methodology method \& Techniques-Second.

xxxv. Lorber, J. (2004). "Night to his day": The social construction of gender. Race, class, and gender in the United States: An integrated study, 6, pp. 54-65.

xxxvi. Leaper, C., \& Robnett, R. D. (2011). Women are more likely than men to use tentative language, aren't they? A metaanalysis testing for gender differences and moderators. Psychology of Women Quarterly, 35(1), 129-142.

xxxvii. Maltz, D. N., \& Borker, R. A. (1982). A cultural approach to male-female miscommunication. A cultural approach to interpersonal communication: Essential readings, 168-185.

xxxviii. Manyozo, L. (2006). Manifesto for Development Communication: Nora Quebral and the Los Baños School of Development Communication editor's note. Asian Journal of Communication. 16: 79-99.

xxxix. Mason, E. S. (1994). Work values: A gender comparison and implications for practice. Psychological Reports, 74(2), 415-418.

xl. Martin, P. Y. (1996). Men, masculinities and management: Gendering and evaluating dynamics. Men as managers, managers as men: Critical perspectives on masculinity, 186-209.

xli. Meeker, B. E., \&Weitzel-O’Neill, P. A. (1998). In Berger, J. \& Zelditch, M. Status, rewards and influence, 379-405.

xlii. Merchant, K. (2012). How men and women differ: Gender differences in communication styles, influence tactics, and leadership styles.CMC Senior Theses. Paper 513.http:// scholarship.claremont.edu/ cmc theses/ 513.

xliii. Miller, N., Maruyama, G., Beaber, R. J., \& Valone, K. (1976). Speed of speech and persuasion. Journal of personality and social psychology, 34(4), 615.

xliv. Morse, J. M. (Ed.). (1994). Critical issues in qualitative research methods. Sage.

xlv. Moser, C. (2015). Gender planning and development: Theory, practice and training. Routledge.

xlvi. Mouton .J. (2011).How to Succeed in Your Masters and Doctoral Studies: A Study of South African Guide and Research Book. Pretoria :Van Schalke Republic.

xlvii. Mulac, A., Bradac, J. J., \& Gibbons, P. (2001). Empirical support for the gender-as-culture hypothesis: An intercultural analysis of male/ female language differences. Human Communication Research, 27(1), 121-152.

xlviii. Mugenda and Mugenda (1999). Research Methods .Quantitative and Qualitative Nairobi:ACTS Press.

xlix. Mugenda and Mugenda. (2008). Social Science Research : Conception, Methodology and Analysis,Nairobi:ACTS Press

l. Ngomba, T. (2016). What is "development" for? Communication sources Development. 3: 29-32.

li. Oso, W. Y., \& Onen, D. (2005). A Guide to writing Research Proposals and Reports.

lii. Parpart, J.L., Rai, S.M. and Staudt, K.A. eds. (2013). Rethinking empowerment: Gender and development in a global/ local world. Routledge.

liii. Pierce, J. L. (1995). Gender trials: Emotional lives in contemporary law firms. Berkeley, CA: University of California Press.

liv. Rao, A., Schmidt, S. M., \& Murray, L. H. (1995). Upward impression management: Goals, influence strategies, and consequences. Human Relations, 48(2), 147-167.

lv. Rashotte, L. (2007). Social influence. The Blackwell encyclopedia of sociology.

lvi. Rees, D., Momanyi, M., Wekundah, J., Oyure, A.O., Andima, D., Musembi, F. and Mwaura, L. (2016). Agricultural knowledge and information systems in Kenya: implications for technology dissemination and development. Overseas development institute (ODI). Agricultural research and extension network (AgREN).

lvii. Ritchie, J., Spencer, L., \& O'Connor, W. (2003). Carrying out qualitative analysis. Qualitative research practice: A guide for social science students and researchers, 2003, 219-62.

lviii. Servaes, J. (2008). Communication for development approaches of some governmental and non-governmental agencies. Communication for development and social change, 201.

lix. Somekh, B., \& Lewin, C. (Eds.). (2005). Research methods in the social sciences. Sage.

lx. Stern, S.J. (1997). The secret history of gender: Women, men, and power in late colonial Mexico.University of North Carolina Press.

lxi. Tannen, D. (1990). You Just Don't Understand: Women and Men in Conversation.

lxii. Ballantine Books, New York. 
lxiii. Thomas, A. (2017). Development. In Gregory, D. Dictionary of Human Geography, 5th edition (pp. 155-56). WileyBlackwell.

lxiv. Treichler, P.A. and Wartella, E. (2006). Interventions: Feminist Theory and Communication Studies .Communication. 9:1-18.

lxv. WHO.(2015).What do mean by 'sex' and 'gender'?http:// www.who.int/ gender/ whatisgender/ en/accessed 4 May 2017

lxvi. Wilkins. K. G. (2016). Communicating Gender and Advocating Accountability in Global Development. The International Journal for Communication Studies, 64(1), 7-24.

lxvii. Winship, J. (2013). Inside Women's Magazines. London: Pandora Press.

lxviii. Wood,J. T (1996). Gendered lives: Communication, gender and culture (2nd ed).

lxix. Orodho, A. J. (2010). Essentials of educational and social science research methods. Nairobi: Masola Publishers.

lxx. Quebral, N.C. (2006). Development communication in a borderless world. Global Times. 3: 33-43.

lxxi. Rogers, E.M. (2016). Communication and development: The passing of the dominant paradigm. Communication Research. 3: 213-240.

lxxii. Sen.G. , Ostlin ,P \& George .A ( 2002) .Engendering International Health : The Challenge of Equity.Cambrigde :MT Press

lxxiii. Servaes, J. ed. (2008). Communication for development and social change. SAGE Publications India.

lxxiv. Schegg, R. and Stangl, B. (2017). Information and communication technologies in Tourism 2017. Springer.

lxxv. Von Hippel, C., Wiryakusuma, C., Bowden, J., \& Shochet, M. (2011). Stereotype threat and female communication styles. Personality and Social Psychology Bulletin, 37(10), 1312-1324. doi:10.1177/ 0146167211410439

lxxvi. Yin, R. K. (2009). Case Study Research: Design and Methods. Essential guide to qualitative methods in organizational research (Vol. 5). In The Information Systems Research Challenge (Harvard Business School Research Colloquium). London: Sage.

lxxvii. World Bank. (2015). Information, Communication Technologies, and infoDev (Program). Information and communications for development: Maximizing mobile. World Bank Publications. 